\title{
AKTIVITAS ANTIOKSIDAN DAN TOTAL FENOLIK RUMPUT LAUT Gracilaria sp. KABUPATEN BREBES
}

\author{
Rifatul Masrikhiyah \\ Program Studi Ilmu Gizi, Fakultas Ilmu Kesehatan, Universitas Muhadi Setiabudi \\ Jalan Pangeran Diponegoro KM 2 Pesantunan, Kec. Wanasari, Kabupaten Brebes, Jawa Tengah
}

Diterima: 5 Januari 2021/Disetujui: 10 Agustus 2021

"Korespondensi: rifatul.masrikhiyah@gmail.com

Cara sitasi: Masrikhiyah R. 2021. Aktivitas antioksidan dan total fenolik rumput laut Gracilaria sp. kabupaten Brebes. Jurnal Pengolahan Hasil Perikanan Indonesia. 24(2): 236-242.

\begin{abstract}
Abstrak
Kabupaten Brebes merupakan salah satu wilayah penghasil rumput laut di provinsi Jawa Tengah dengan luas tambak rumput laut sebanyak 4.350 ha dari totalluas tambak sebesar 12.748 ha yang menghasilkan 200 ton rumput laut kering per bulan. Rumput laut dapat digunakan sebagai sumber antioksidan karena mengandung senyawa bioaktif terutama untuk golongan senyawa fenolik, flavonoid dan alkaloid. Tujuan penelitian ini adalah untuk mengkaji aktivitas antioksidan dan total fenolik bubuk rumput laut Gracilaria sp. kabupaten Brebes. Parameter yang diamati yaitu kapasitas penangkapan radikal bebas menggunakan metode radical scavenging activity (RSA) DPPH dan total fenolik menggunakan metode Folin-Ciocalteu. Penelitian ini menggunakan rancangan acak lengkap (RAL) yang terdiri dari dua perlakuan (bubuk rumput laut dari bahan baku segar dan kering) dan dilakukan tiga kali pengulangan. Bubuk rumput laut Gracilaria sp. Kabupaten Brebes dari bahan baku segar memiliki kandungan total fenol dan kapasitas penangkapan radikal bebas yang lebih tinggi dibandingkan dengan bahan baku kering. Kandungan total fenol bubuk rumput laut Gracilaria sp. kabupaten Brebes sekitar 4,35-4,49 (mg GAE/100 g) dan aktivitas antioksidannya sekitar 15,90-42,50 (\%RSA). Terdapat perbedaan kapasitas penangkapan radikal bebas menggunakan bahan baku rumput laut basah dan kering.
\end{abstract}

Kata kunci: Gracilaria sp.; aktivitas antioksidan; total fenolik

\section{Antioxidant Activity and Total Phenolic of Seaweed Gracilaria sp. from Brebes}

\begin{abstract}
Brebes regency is one of the seaweed producing areas in Central Java province with an area of seaweed ponds as much as 4,350 ha of the total pond area of 12,748 ha that produces 200 tons of dried seaweed per month. Seaweed can be used as a source of antioxidants because it contains bioactive compounds especially for phenolic compounds, flavonoids and alkaloids. The purpose of this study is to examine the antioxidant activity and total phenolic powder of seaweed Gracilaria sp Brebes Regency. The observed parameters are free radical capture capacity using DPPH radical scavenging activity (RSA) method and total phenolic using Folin-Ciocalteu method. This study used a Complete RandomIzed Design (RAL) consisting of 2 treatments (seaweed powder from fresh and dry raw materials) and conducted 3 repetitions. Gracilaria sp Seaweed Powder Brebes from fresh raw materials has a total phenol content and a higher free radical catching capacity compared to dry raw materials. The total content of seaweed powder phenol Gracilaria sp Brebes district is about $4.35-4.49$ ( $\mathrm{mg} \mathrm{GAE} / 100 \mathrm{~g}$ ) and its antioxidant activity is about $15.90-42.50$ (\%RSA). There are differences in the capture capacity of free radicals using wet and dry seaweed raw materials.
\end{abstract}

Keyword: Gracilaria sp.; antioxidant activity; total phenolic 


\section{PENDAHULUAN}

Kabupaten Brebes merupakan salah satu wilayah penghasil rumput laut di provinsi Jawa Tengah dengan total luas tambak rumput laut sebesar 4.350 ha dari total luas tambak sebesar 12.748 ha yang menghasilkan 200 ton rumput laut kering per bulan (Dinas Kelautan dan Perikanan Kabupaten Brebes 2016). Pengolahan rumput laut masih sangat terbatas dilakukan oleh masyarakat padahal kandungan zat gizi rumput laut memiliki manfaat bagi tubuh seperti yodium, serat pangan dan antioksidan. Chaidir (2006) menyatakan bahwa terdapat yodium 29,94 ppm (\%bk) dan serat pangan 9,76\% (\%bb) dalam rumput laut Gracilaria sp. Selain mengandung yodium yang tinggi dan sebagai sumber serat pangan, rumput laut mengandung senyawa bioaktif yang bermanfaat sebagai sumber antioksidan terutama untuk golongan senyawa fenolik, flavonoid dan alkaloid (Nawaly 2013). Sanger (2018) menyatakan bahwa Gracilaria salicornia dapat berfungsi sebagai pangan fungsional sumber pigmen dan antioksidan alami dan diperkuat dengan penelitian yang dilakukan Purwaningsih (2020) bahwa Gracilaria sp. aman dan dapat digunakan sebagai bahan baku pangan fungsional.

Rumput laut Gracilaria sp. dapat dijadikan agar bakto dengan penambahan kitosan sebagai absorben (Abdullah et al. 2008), agar native dengan bantuan gelombang ultrasonik (Uju 2018) dan dapat dimanfaatkan dalam pembuatan permen jeli (Salamah 2006). Rumput laut merupakan sumber serat larut yang lebih baik dibandingkan pangan dari tanaman darat yang umumnya tinggi serat tidak larutnya (Dwiyitno 2011). Kandungan serat yang tinggi terutama serat pangan dapat dimanfaatkan dalam pembuatan produk makanan, seperti penelitian yang dilakukan oleh Yakhin (2013) mengenai pembuatan sosis ikan dengan penambahan tepung rumput laut Gracilaria sp. menghasilkan sosis ikan lele dengan tepung rumput laut memiliki kandungan serat pangan yang lebih tinggi dibandingkan dengan sosis ikan komersial. Selain dapat digunakan dalam pembuatan produk makanan rumput laut Gracilaria sp. juga dapat digunakan sebagai antimikroba dengan menghambat pertumbuhan mikroba. Kaimudin (2020) menyatakan bahwa ekstrak Gracilaria sp. 3\% mempunyai potensi untuk menghambat pertumbuhan total bakteri ikan.

Senyawa bioaktif yang terdapat pada rumput laut memiliki kemampuan untuk menetralkan radikal bebas di dalam tubuh, oleh karena itu dapat dijadikan sebagai antioksidan. Proses oksidasi dapat dicegah atau diperlambat oleh antioksidan yang merupakan zat yang terkandung pada bahan pangan baik berupa zat gizi maupun zat non-gizi (Tamat 2007; Winarti 2005). Senyawa bioaktif yang terdapat pada rumput laut dapat dijadikan alternatif penggunaan antioksidan alami. Penyakit degenaratif dan peroksidasi lipid dapat dicegah atau dihambat menggunakan antioksidan alami. Selain itu antioksidan alami dapat digunakan untuk perlindungan tubuh untuk menghindari kerusakan yang disebabkan spesies oksigen reaktif tanpa efek samping (Ganesan 2008). Uji toksisitas menunjukkan bahwa antioksidan sintetis bersifat karsinogenik dibandingkan dengan antioksidan alami. Perkembangan sel kanker dan kerusakan hati dapat dipicu dan disebabkan oleh zat karsinogenik (Kumar 2013). Rumput laut Gracilaria sp. memiliki kandungan senyawa fenol sebesar 0,89\%; karotenoid sebesar 1.776,63 $\mu \mathrm{g} / 100 \mathrm{~g}$ sampel dan aktivitas antioksidan atau kemampuan menangkap radikal bebas sebesar 9,67\% (Julyasih 2009).

Kandungan air yang cukup tinggi pada rumput laut berakibat umur simpan rumput laut pendek, hal tersebut dipandang perlu adanya alternatif pengolahan rumput laut untuk meningkatkan nilai tambah, untuk mempermudah penyimpanan dan meminimalisasi kerusakan dengan cara pembuatan bukti rumput laut. Potensi rumput laut yang sangat luas dan belum banyak dilakukan penelitian menggunakan rumput laut Gracilaria sp. yang berasal dari kabupaten Brebes mendorong dilakukannya penelitian mengenai kandungan senyawa bioaktif pada bubuk rumput laut Gracilaria sp. kabupaten Brebes. Pemanfaatan rumput laut Gracilaria sp. dalam pembuatan bubuk masih sangat rendah di kalangan petani rumput laut di daerah Kabupaten Brebes. 
Penelitian ini bertujuan menganalisis aktivitas antioksidan dan total fenolik bubuk rumput laut Gracilaria sp. kabupaten Brebes. Penelitian ini memiliki keutamaan dalam pengembangan dan pengoptimalan pangan fungsional berbasis sumber daya lokal sebagai sumber antioksidan.

\section{BAHAN DAN METODE Bahan dan Alat}

Bahan baku yang digunakan yaitu rumput laut Gracilaria sp. segar dan kering yang diambil dari petani rumput laut yang ada di desa Randusanga kecamatan Brebes kabupaten Brebes dan bahan kimia untuk menganalisis kandungan total fenol dan aktivitas antioksidan. Peralatan yang digunakan dalam penelitian ini yaitu peralatan yang dipakai dalam pembuatan bubuk rumput laut Gracilaria sp. dan peralatan yang dipakai dalam menganalisis kandungan total fenol dan aktivitas antioksidan bubuk rumput laut Gracilaria sp.

\section{Metode Penelitian}

Penelitian ini terdiri dari dua tahapan utama yaitu pembuatan bubuk rumput laut dan analisis total fenol serta analisis aktivitas antioksidan.

\section{Pembuatan bubuk rumput laut}

Pembuatan tepung rumput laut menjadi bubuk rumput laut menggunakan bahan baku segar dan kering. Bahan baku segar dan kering yang dikumpulkan kemudian dibersihkan dan dicuci; direndam dan dipucatkan menggunakan larutan pemucatan yaitu akuades, $\mathrm{CaO} 0,5 \%$ selama 5 menit. Pengeringan menggunakan oven dengan suhu $45^{\circ} \mathrm{C}$ selama 18 jam. Pengecilan ukuran menggunakan blender kemudian dilakukan pengayakan menggunakan ayakan 100 mesh dan dihasilkan bubuk rumput laut Gracilaria sp.

\section{Analisis proksimat bubuk rumput laut Gracilaria sp.}

Analisis proksimat bubuk rumput laut Gracilaria sp. meliputi analisis kadar air menggunakan metode oven (Sudarmadji et al. 2007), analisis kadar abu menggunakan metode tanur (Sudarmadji et al. 2007), kadar lemak menggunakan metode soxhlet (Sudarmadji et al. 2007), analisis kadar protein menggunakan metode kjeldahl (Sudarmadji et al. 2007), analisis kadar karbohidrat (by difference).

Analisis total fenol (Zubia et al. 2007)

Bubuk rumput laut yang telah diekstrak sebanyak 0,2 $\mathrm{mL}$ ditambahkan akuades sebesar 15,8 mL dan reagen Folin-Ciocalteu 1 $\mathrm{mL}$ kemudian dikocok dan didiamkan selama 8 menit, dicampurkan dengan $3 \mathrm{~mL} \mathrm{Na}_{2} \mathrm{CO}_{3}$ $10 \%$ kemudian didiamkan selama 1 jam pada suhu ruang. Absorbansi diukur menggunakan panjang gelombang maksimum (panjang gelombang $517 \mathrm{~mm}$ ) dengan spektrofotometer UV-Vis.

\section{Analisis kapasitas penangkapan radikal bebas (Sheikh et al. 2009)}

Sebanyak $2 \mathrm{~mL}$ larutan bubuk rumput laut Gracilaria sp. dicampur dengan $2 \mathrm{~mL}$ larutan DPPH 0,16 mM dalam metanol. Campuran lalu dihomogenkan dengan bantuan vortex selama 1 menit dan dibiarkan selama 30 menit lalu absorbansinya diukur menggunakan spektrofotometer UV-Vis pada panjang gelombang $517 \mathrm{~mm}$. Penurunan absobansi menunjukkan peningkatan kemampuan menangkap radikal bebas DPPH yang dihitung sesuai dengan peneliti terdahulu (Sheikh et al. 2009).

\section{Rancangan percobaan}

Penelitian ini terdiri dari dua perlakuan yaitu bubuk rumput laut dari bahan baku basah dan bahan baku kering. Rancangan percobaan dalam penelitian ini adalah rancangan acak lengkap (RAL) yang terdiri dari dua perlakuan dengan tiga kali ulangan. Data dianalisis menggunakan Uji $\mathrm{F}$ dengan taraf kepercayaan 95\%.

\section{HASIL DAN PEMBAHASAN Karakteristik Kimia Bubuk Rumput Laut Gracilaria sp.}

Karakteristik kimia bubuk rumput laut Gracilaria sp. yang diteliti dalam penelitian ini yaitu kadar air, abu, lemak, protein, dan karbohidrat yang diukur dengan tiga 
kali pengulangan. Hasil analisis ragam karakteristik kimia bubuk rumput laut Gracilaria sp. dapat dilihat pada Table 1.

Kadar air rata-rata bubuk rumput laut pada perlakuan perendaman $\mathrm{CaO}$ selama 5 menit dari bahan baku basah lebih tinggi dibandingkan perlakuan perendaman $\mathrm{CaO}$ selama 5 menit dari bahan baku kering. Kadar air bubuk rumput laut akan menentukan umur simpannya, yaitu semakin tinggi kadar air maka umur simpannya semakin rendah. Kadar air bubuk rumput laut dalam penelitian ini lebih rendah dibandingkan kadar air tepung rumput laut pada penelitian Purwaningsih (2020) dan masih sesuai dengan peraturan SNI 2690:2015 dengan jumlah maksimal yaitu $12 \%$.

Kadar abu rata rata bubuk rumput laut tidak jauh berbeda antara perlakuan perendaman $\mathrm{CaO}$ selama 5 menit dari bahan baku basah dan perlakuan perendaman $\mathrm{CaO}$ selama 5 menit dari bahan baku kering. Kadar abu bubuk rumput laut penelitian ini lebih tinggi dibanding dengan rumput laut penelitian Munandar et al. (2019) yaitu $15,08 \%$ dan penelitian Purwaningsih (2020) yaitu $10,19 \%$, hal ini karena rumput laut pada penelitian diambil dari perairan dan habitat yang berbeda.

Kadar lemak rata rata bubuk rumput laut tidak jauh berbeda antara perlakuan perendaman $\mathrm{CaO}$ selama 5 menit dari bahan baku basah dan perlakuan perendaman $\mathrm{CaO}$ selama 5 menit dari bahan baku kering. Kadar lemak rata rata pada penelitian yaitu $3,38 \%$ dan 3,33\% yang artinya kadar lemak pada penelitian ini masih dalam kisaran kadar lemak rumput laut pada umumnya, yaitu menurut Khairy and El Shafay (2013) kadar lemak untuk semua jenis rumput laut dikategorikan rendah sekitar 0,9\%-40\%.

Kadar protein rata rata bubuk rumput laut tidak jauh berbeda antara perlakuan perendaman $\mathrm{CaO}$ selama 5 menit dari bahan baku basah dengan perlakuan perendaman $\mathrm{CaO}$ selama 5 menit dari bahan baku kering. Kadar protein bubuk rumput laut penelitian ini lebih rendah dibanding dengan rumput laut penelitian Munandar et al. (2019) yaitu $8,77 \%$ dan penelitian Purwaningsih (2020) yaitu $12,78 \%$ karena habitat rumput laut yang berbeda. Habitat yang berbeda dapat memengaruhi unsur hara nitrat dan fosfat bubuk rumput laut. Hasil penelitian yang dilakukan oleh Yudiati et al. (2020) menunjukkan perubahan kandungan nitrat dan fosfat pada rumput laut Gracilaria sp. dapat menyebabkan perubahan kandungan protein pada sel rumput laut.

Kadar karbohidrat rata-rata bubuk rumput laut pada perlakuan perendaman $\mathrm{CaO}$ selama 5 menit dari bahan baku basah lebih rendah dibandingkan perlakuan perendaman $\mathrm{CaO}$ selama 5 menit dari bahan baku kering. Kadar karbohidrat bubuk rumput laut penelitian ini lebih rendah dibanding dengan rumput laut penelitian Munandar et al. (2019) yaitu 64\% dan penelitian Purwaningsih (2020) yaitu $65,13 \%$. Hal tersebut karena habitat yang berbeda akan menyebabkan perbedaan polisakarida/karbohidrat yang terkandung di dalam rumput laut.

Table 1 Chemical characteristics of seaweed Gracilaria sp. powder

\begin{tabular}{lrr}
\hline \multirow{2}{*}{ Parameter } & \multicolumn{2}{c}{ Mean \pm SD $(\%)$} \\
\cline { 2 - 3 } & \multicolumn{1}{c}{ P1 } & \multicolumn{1}{c}{ P2 } \\
\hline Moisture & $8.06 \pm 0.25$ & $7.45 \pm 0.11$ \\
Ash & $32.44 \pm 0.14$ & $32.32 \pm 0.04$ \\
Lipid & $3.38 \pm 0.03$ & $3.33 \pm 0.05$ \\
Protein & $2.97 \pm 0.09$ & $2.88 \pm 0.12$ \\
Carbohydrate & $53.10 \pm 0.33$ & $54.04 \pm 0.08$ \\
\hline
\end{tabular}

Note : P1=Seaweed Gracilaria sp. powder with soaking $\mathrm{CaO} 0.5 \%$ for 5 minutes from fresh raw materials; P2=Seaweed Gracilaria sp. powder with soaking $\mathrm{CaO} 0.5 \%$ for 5 minutes from dry raw materials. 


\section{Kapasitas Penangkapan Radikal Bebas dan Total Fenolik}

Bubuk rumput laut Gracilaria sp. yang dihasilkan berasal dari bahan baku rumput laut segar dan rumput laut kering yang didapatkan dari desa Randusanga kecamatan Brebes kabupaten Brebes. Data kapasitas penangkapan radikal bebas dan total fenolik didapat dari analisis kapasitas penangkapan radikal bebas dan total fenolik bubuk rumput laut yang dianalisis menggunakan metode DPPH dan metode folin cioucalteu. Data hasil analisis dapat dilihat pada Table 2.

Penetuan kapasitas penangkapan radikal bebas bubuk rumput laut Gracilaria sp. menggunakan panjang gelombang 517 $\mathrm{nm}$ yang merupakan panjang gelombang maksimum sebagai aktivitas penangkalan radikal bebas dari bubuk rumput laut. Data kapasitas penangkapan radikal bebas bubuk rumput laut Gracilaria sp. terendah sebesar $15,90 \%$ RSA pada bubuk rumput laut Gracilaria sp. dari bahan baku kering sedangkan tertinggi sebesar $42,50 \%$ RSA pada bubuk rumput laut Gracilaria sp. dari bahan baku segar. Data hasil analisis kapasitas penangkapan radikal bebas menunjukkan bahwa rata rata kapasitas penangkapan radikal bebas pada bubuk rumput laut Gracilaria sp. dari bahan segar $(42,1 \%$ RSA) lebih tinggi dibandingkan dengan bubuk rumput laut Gracilaria sp. dari bahan kering (16,63\% RSA).

Pengujian kapasitas penangkapan radikal DPPH merupakan pengujian aktivitas antioksidan yang sederhana dan paling banyak digunakan (White et al. 2014, Kedare \& Singh 2011). Bubuk rumput laut dari bahan baku segar menunjukkan bahwa kapasitas penangkapan radikal bebas lebih besar dibandingkan dengan aktivitas antioksidan pada bubuk rumput laut Gracilaria sp. dari bahan baku kering. Hal tersebut dikarenakan perlakuan pengeringan yang lebih lama pada bubuk rumput laut dari bahan baku kering yang dalam proses pembuatannya mengalami dua kali pengeringan. Menurut penelitian yang dilakukan oleh Adri (2013) mengenai aktivitas antioksidan daun sirsak berdasarkan variasi lama pengeringan menunjukkan bahwa aktivitas antioksidan semakin rendah nilainya pada daun sirsak dengan lama pengeringan yang paling lama.

Kandungan total fenol pada bubuk rumput laut Gracilaria sp. ditentukan menggunakan metode Folin-Ciocalteu. Data total fenolik bubuk rumput laut Gracilaria sp. terendah sebesar 4,35 mg GAE/100 g pada bubuk rumput laut Gracilaria sp. dari bahan baku kering sedangkan tertinggi sebesar 4,49 mg GAE/100 g pada bubuk rumput laut Gracilaria sp. dari bahan baku segar. Berdasarkan uji statistika menunjukkan bahwa total fenolik pada bubuk rumput laut Gracilaria sp. dari bahan baku basah dan bahan baku kering tidak berbeda nyata. Data hasil analisis total fenolik menunjukkan bahwa rata rata total fenolik pada bubuk rumput laut Gracilaria sp. dari bahan baku basah $(4,47 \mathrm{mg}$ GAE/100 g) sedikit lebih tinggi dibandingkan dengan bubuk rumput laut Gracilaria sp. dari bahan baku kering (4,39 mg GAE/100 g). Hasil analisis total fenolik dengan metode Folin-Ciocalteu menunjukkan bahwa bubuk rumput laut Gracilaria sp. dari bahan baku basah memiliki total fenol yang sedikit lebih tinggi dibandingkan dengan bubuk rumput laut Gracilaria sp. dari bahan baku kering. Hal tersebut karena perlakuan pengeringan

Table 2 Free radical capture capacity and total phenolic of seaweed Gracilaria sp. powder

\begin{tabular}{lcc}
\hline \multirow{2}{*}{ Parameter } & \multicolumn{2}{c}{ Mean \pm SD (\%) } \\
\cline { 2 - 3 } & P1 & P2 \\
\hline $\begin{array}{l}\text { Antioxidant Activity } \\
\text { (\% RSA) }\end{array}$ & $42.10 \pm 0.40$ & $16.63 \pm 0.66$ \\
$\begin{array}{l}\text { Total Phenolic } \\
\text { (mg GAE/100 g) }\end{array}$ & $4.47 \pm 0.02$ & $4.39 \pm 0.058$ \\
\hline
\end{tabular}

Note : $\mathrm{P} 1=$ Seaweed Gracilaria sp. powder with soaking $\mathrm{CaO} 0.5 \%$ for 5 minutes from fresh raw materials; P2=Seaweed Gracilaria sp. powder with soaking $\mathrm{CaO} 0.5 \%$ for 5 minutes from dry raw materials. 
yang lebih lama pada bubuk rumput laut dari bahan baku kering yaitu proses pembuatan bubuk rumput lautnya mengalami dua kali pengeringan. Jahangiri et al. (2011) menyatakan bahwa beberapa fenol dapat rusak karena adanya proses pengeringan yang meliputi suhu pengeringan atau waktu pengeringan. Suhu yang berbeda dan lama pengeringan pada Padina sp menyebabkan total fenol yang berbeda, yaitu semakin tinggi suhu pengeringan dan waktu pengeringan meyebabkan penurunan total fenol Padina sp. (Husni 2017, Hikmah et al. 2009).

\section{KESIMPULAN}

Kandungan total fenol dan kapasitas penangkapan radikal bebas pada bubuk rumput laut Gracilaria sp. kabupaten Brebes dari bahan baku segar memiliki kandungan yang lebih tinggi dibandingkan dengan dari bahan baku kering. Kandungan total fenol bubuk rumput laut Gracilaria sp. kabupaten Brebes sekitar 4,35-4,49 (mg GAE/100 g) dan aktivitas antioksidannya sekitar 15,9042,50 (\% RSA). Terdapat perbedaan kapasitas penangkapan radikal bebas menggunakan bahan baku rumput laut basah dan kering sedangkan total fenol tidak berbeda nyata.

\section{UCAPAN TERIMA KASIH}

Ucapan terima kasih kami sampaikan kepada Direktur Riset dan Pengabdian kapada Masyarakat (DRPM), Kementerian Riset dan Teknologi-Badan Riset dan Inovasi Nasional Republik Indonesia sebagai pemberi dana hibah Penelitian Dosen Pemula tahun pelaksanaan 2020 .

\section{DAFTAR PUSTAKA}

Abdullah A, Suptijah P, Suwandi R. 2008. Karakteristik fisik dan kimia agar bakto dengan penambahan kitosan.Buletin Teknologi Hasil Perikanan. 11(1): 28-39.

Adri D, Hersoelistyorini W. 2013. Aktivitas antioksidan dan sifat organoleptik teh daun sirsak (Annona muricata Linn.) berdasarkan variasi lama pengeringan. Jurnal Pangan dan Gizi. 4(1): 1-12.

Chaidir A. 2006. Kajian rumput laut sebagai sumber serat alternatif untuk minuman berserat. [Tesis]. Bogor: Institut Pertanian
Bogor.

Chew YL, Lim YY, Omar M, Khoo KS. 2008. Antioxidant activity of three edible seaweeds from two areas in South East Asia. LWT-Food Science and Technology. 41(6):1067-1072.

Dinas Kelautan dan Perikanan Kabupaten Brebes. 2016. Laporan Statistika Produksi Perikanan Budidaya Pembenihan dan Nilainya. Brebes: Dinas Kelautan dan Perikanan Kabupaten Brebes.

Dwiyitno D. 2010. Seaweed as a potential source of dietary fiber. Squalen Bulletin of Marine and Fisheries Postharvest and Biotechnology. 6(1): 9-17.

Ganesan P, Kumar CS, Bhaskar N. 2008. Antioxidant properties of methanol extract and its solvent fractions obtained from selected Indian red seaweeds. Bioresource Technology. 99(8): 2717-2723.

Hikmah AF, Budhiyanti SA, Ekantari N. 2009. Pengaruh pengeringan terhadap aktivitas antioksidan Spirulina platensis. Prosiding Seminar Nasional Tahunan VI Hasil Penelitian Perikanan dan Kelautan. (4):111).

Husni A, Putra DR, Lelana IYB. 2014. Aktivitas antioksidan Padina sp. pada berbagai suhu dan lama pengeringan. Jurnal Pascapanen dan Bioteknologi Kelautan dan Perikanan. 9(2): 165-173.

Jahangiri Y, Ghahremani H, Torghabeh JA, Salehi EA. 2011. Effect of temperature and solvent on the total phenolic compounds extraction from leaves of Ficus carica. Journal of Chemical and Pharmaceutical Research. 3(5):253-259.

Julyasih KSM, Wirawan IGP, Harijani WS, Widajati W. 2009. Aktivitas antioksidan beberapa jenis rumput laut (seaweeds) komersial di Bali. Prosiding Seminar Akselerasi Pengembangan Teknologi Pertanian dalam Mendukung Revitalisasi Pertanian. Fakultas Pertanian dan LPPM UPN Veteran.

Kaimudin M, Moniharapon T, Mailoa MN, Pattipeilohy F. 2020. Efektivitas ekstrak Gracilaria sp. dalam menghambat pertumbuhan mikroba ikan layang dan tuna pada penyimpanan suhu 
ruang. Jurnal Pengolahan Hasil Perikanan Indonesia. 23(3): 523-531.

Kedare SB, Singh RP. 2011. Genesis and development of DPPH method of antioxidant assay. Journal of Food Science and Technology. 48(4): 412-422.

Kumar SR, Hosokawa M, Miyashita K. 2013. Fucoxanthin: A marine carotenoid exerting anti-cancer effects by affecting multiple mechanisms. Marine drugs. 11(12): 5130-5147.

Molyneux, P., 2004. The use of the stable free radical diphenylpicrylhydrazyl (DPPH) for estimating antioxidant activity. Songklanakarin Journal of Science and Technology. 26(2): 211-219.

Munandar A, Surilayani D, Haryati S, Sumantri MH, Aditia RP, Pratama G. 2019. Characterization flour of two seaweeds (Gracilaria spp. and Kappaphycus alvarezii) for reducing consumption of wheat flour in Indonesia. IOP Conference Series: Earth and Environmental Science. 383 (2019) 012009.

Nawaly H, Susanto AB, Uktolseja JL. 2013. Senyawa bioaktif dari rumput laut sebagai antioksidan. Proceeding Biology Education Conference: Biology, Science, Enviromental, and Learning . 10(1):

Purwaningsih S, Deskawati E. 2020. Karakteristik dan aktivitas antioksidan rumput laut Gracilaria sp. asal Banten. Jurnal Pengolahan Hasil Perikanan Indonesia. 23(3): 503-512.

Salamah E, Erungan AC, Retnowati Y. 2006. Pemanfaatan Gracilaria sp. dalam pembuatan permen jelly. Jurnal Pengolahan Hasil Perikanan Indonesia. 9(1):

Sanger G, Kaseger BE, Rarung LK, Damongilala L. 2018. Potensi beberapa jenis rumput laut sebagai bahan pangan fungsional, sumber pigmen dan antioksidan alami. Jurnal Pengolahan Hasil Perikanan Indonesia. 21(2): 208-217.

Sheikh TZB, Yong CL, Lian MS. 2009. In vitro antioxidant activity of the hexane and methanolic extracts of Sargassum baccularia and Cladophora patentiramea. Journal of Applied Sciences. 13(9): 24902493.

Sudarmadji S, Bambang H, Suhardi. 2007. Analisis Bahan Makanan dan Pertanian. Liberty. Yogyakarta. ID

Tamat SR, Wikanta T, Maulina LS. 2007. Aktivitas antioksidan dan toksisitas senyawa bioaktif dari ekstrak rumput laut hijau Ulva reticulata Forsskal. Jurnal Ilmu Kefarmasian Indonesia. 5(1):31-36.

Uju, Santoso J, Ramadhan W, Abrory MF. 2018. Extraction of native agar from Gracillaria sp with ultrasonic acceleration at low temperature. Jurnal Pengolahan Hasil Perikanan Indonesia. 21(3):414-422.

White PAS, Oliveira RCM, Oliveira AP, Serafini MR, Araújo AAS, Gelain Moreira DPJCF, Almeida JRGS, Quintans JSS, Quintan Junior LJ, Santos MRV. 2014. Antioxidant activity and mechanisms of action of natural compounds isolated from lichens: A Systematic review. Molecules. 19:1449614527.

Winarti C, Nurdjanah N. 2005. Peluang tanaman rempah dan obat sebagai sumber pangan fungsional. Jurnal Litbang Pertanian. 24(2): 47-55.

Yakhin LA, Wijaya KM, Santoso J. 2013. Peningkatan kualitas gel sosis ikan lele dengan penambahan tepung Gracilaria gigas. Jurnal Pengolahan Hasil Perikanan Indonesia. 16(2):177-182.

Yudiati E, Ridho A, Nugroho AA, Sedjati S, Maslukah L. 2020. Analisis kandungan agar, pigmen dan proksimat rumput laut Gracilaria sp. pada reservoir dan biofilter tambak udang Litopenaeus vannamei. Buletin Oseanografi Marina. 9(2): 133140.

Zubia M, Robledo D, Freile-Pelegin Y. 2007. Antioxidant activities in marine macroalgae from the coasts of Quintana Roo and Yucatan, Mexico. Journal of Applied Phycology. 19(5):449-458. 